\title{
Effective Business Strategy for International Strategic Performance: An Empirical Study of Chinese Construction Firms
}

\author{
Mirzaeva Dilafruz Faziljanovna, GaoYongqian \\ School of Management, Huazhong University of Science and Technology, Wuhan, China \\ Email (corresponding author): dilafruzmba@yandex.com
}

\begin{abstract}
To build on the research of strategic management we conducted an empirical study in the context of international performance. Three principal strategies, according to Porters generic strategy theory: cost leadership costfocus and differentiation respectively, were tested in our research model. Quantitative empirical analysis of international strategy on a sample of 58 Chinese firms was conducted to determine strategies that lead to enhanced strategic performance. We utilized survey strategy encompassing questionnaire data collection. The collected data was analyzed using SPSS statistical package. Inference statistics consisting of correlation analysis and multiple regression analysis were performed. Findings of the study suggest that cost leadership and differentiation strategies impact strategic performance significantly, whereas cost-focus does not. A value of appropriate international business strategy is illustrated by supporting a relationship between strategy and international performance. The originality of contributions of the study lies in the fact that the generic business strategies' impact on strategic performance is tested on an international market on the sample of Chinese firms. These notions enrich existing body of knowledge on strategic management. Therefore, companies conducting their business operations internationally should consider forming and implementing strategies of differentiation and cost leadership to achieve optimal business results.
\end{abstract}

Keywords: International business strategy, Cost leadership, Differentiation, Cost focus, Strategic performance

\section{Introduction}

International economic growth and globalization have led to changing customer and investor demands, severe market competition and increased uncertainty. Surviving under these new circumstances requires smart play by companies, which involves coming up with new and innovative products and services, delivering higher quality at a lower price, enhancing the efficiency of operations and processes, improving productivity, reducing costs and ultimately making the customer happy. Clear strategy creation and implementation are key points for attaining such outcomes.

Business strategy is an essential part of conducting business operation as it directly influences the outcome and result of firm performance (Emeka, 2015). Since choice of business strategy influences various organizational outcomes, forming and implementing optimal strategy to suit the context of business is of significant value in maximizing company profits and minimizing economic risks (Shapiro, 1989). Strategy should be formed based on the knowledge about the international market and the characteristics of the host environment. Recent studies in strategic management explore the characteristics of resources and processes of companies that create competitive advantages, consequently enabling sustainable performance. These research studies are mostly done in the context of of domestic firms and their strategy on local markets. Studies aiming to explain international business strategies that utilize a strong theoretical foundation are fairly scarce (Lages, Jap, \& Griffith, 2008; Morgan, Kaleka, \& Katsikeas, 2004). In our study however, we link the concept of strategy with the strategic performance of companies on international markets. 
The study contributes to the existing literature by precisely addressing these limitations to examine international business strategy and its impact on strategic market performance. As the main purpose of the study, the research attempts to determine whether the international business strategy that the companies operating within the construction firms lead to international success. Following research questions, we aim to answer in this study: What are the business strategies that service firms should use in order to boost strategic performance on international market? Do following strategies: differentiation, cost leadership and cost-focus affect international strategic performance? What strategy do SMEs in a Chinese service sector mostly employ?

\section{Porters generic strategies and their significance}

At the international level, organizations require sustainable competitive advantage to cope with changes and to succeed in creating, sustaining and using competitive advantage through strategic management (Aghazadeh, 2015). Organizations can also form strategies that their implementation results in a sustainable competitive advantage. Characteristics of each strategy are strongly related to the main element - the company's competitive advantage (Barney, 1991), which can differ depending on the strong sides of the company, the use of innovations during the process of production, or low prices, high quality of service. According to Aghazadeh (2015), organizations must consider innovative knowledge as a new input to sustain competitive advantage and to improve intelligent marketing strategy. In addition to this, business strategy has been a subject of various types of research, for instance, a great number of studies emphasize how business strategy plays a crucial role in determining organizational outcomes (Sabherwal \& Chan, 2001).

Strategy is a concept used to express a general program of actions of an enterprise in a bid to achieve its objectives. According to Emeka et al. (2015), strategy is the determination of basic long-term goals and objectives of an enterprise and the selection of course of action and allocation of resources required to carry out these goals. Therefore, strategy can be observed as the process of deciding what will constitute the objectives of an organization, the differences that are demanded in the objectives, the resources that are expected to be used in order to achieve the objectives and the polices that will direct the acquisition, use and disposition of the resources. Moreover, strategy can be described as the comprehensive program for establishing and accomplishing an organization's objectives as well as organization's response to its environment over time.

Furthermore, based on the description given by Porter (2008), the strategy of companies can also be considered as a tool for realization of goals by help of policies, which are named as "means", while the goals are "ends". The overall thought is that there are many benefits from well-conceived strategy and the company, which intends to enter the international market, cannot do that without well-planned strategy. The ignorance of the importance of strategy can result in a loss of customer and resistance by workers to changes. The biggest problematic area is in its application to planning, organizational structure and design, environmental and technological changes. In conclusion, strategy formulation and its implementation enables organizations to thrive and grow and also set the company in a position where it will continue to secure its productive activities and reduce environmental uncertainties in areas of constraints, threats and opportunities.

\section{Development of the research model}

The vast body of literature on strategy demonstrates its significance in influencing organizational outcomes. In order to confirm this notion on the international environment, we have chosen three principal strategies, namely, cost-focus, cost leadership and differentiation to be tested in our research model. The value of appropriate international business strategy is illustrated by relationships between strategy and international performance as presented in this section.

\subsection{Differentiation impact on international market performance}

Nowadays, due to huge variety and abundance of various firms, especially on the international level, many companies put their efforts into being different, to make their products distinctive from others (Porter, 1976). One of the most popular strategies used by many companies is differentiation. The company, which is planning to enter the global market, should be ready to have serious competitors. However, by using this type of strategy, companies open themselves to a huge variety of techniques and features that potentially help them in becoming unique in eyes of their 
customers. Therefore, participants of the international market "race for customers" can use various tools to be unique in comparison with their rivals. Companies can create special attitude to their product by associating it with the social status of the customers; Swiss watches can serve as an example of this technique. As it was mentioned in the example, companies aim to establish high prices for their products, partly because of the expenses on the promotional services, emphasizing the feature of the product, service or company itself to be one special reason, but mostly high price to be a symbol of uniqueness (Tungate, M. 2009). Competitive advantage, stipulated by differentiation can have roots both in physical and nonphysical characteristics of the product or service (Chamberlin, 1965). Finally, modern companies rely not only on the distinctive features of the product, but also on attributes of the company like logo and advertisements, to be memorable for customers. Thus, marketing tools are of great importance as a part of differentiation strategy (Porter, 1976).

\section{H1: Differentiation strategy has a positive impact on international market performance}

\subsection{Cost focus strategy impact on international market performance}

Another generic strategy that potentially has impact on strategic performance, which was described by Porter (1990), is focus strategy. The main characteristic is focus, determining target market, country, customer group, geographic segment that the company serves. There are two types of focus strategies; the first one is focusing on the cost, meanwhile another on the differentiation. However, within our study, we considered cost-focus only. The key point of this strategy is to determine target segment and specialize in the production for this segment only. When operating in this way, company decreases its expenses, often having high prices for its goods or services, as its product offering is unique. Moreover, as for customers, it allows them to enjoy VIP service and to be flexible in making special orders, vary in design and image of their purchases. However, cost focus strategy does not always mean high prices. The word "special" is more appropriate in this case. Companies can offer unique low prices, incredible discounts only for special customers like for old people, students, children, and handicapped people. (Wright, 1987). Nonetheless, this technique makes the firm quite sensible to the orders of their customers, the amount of which is quite narrowed. In this case, small firms are more successful by orienting only on particular buyer.

\section{H2: Cost focus strategy has a positive impact on international market performance}

\subsection{Cost leadership strategy impact on international market performance}

The decision of being successfully admitted by the international audience can be supported by the offer of relatively low prices. The core idea of cost leadership strategy is occupation of big market share, which can be reached by reducing the expenses of the company. By decreasing the expenses, the company is freer to vary its prices and establishing the lowest ones, which it can afford.

It is undoubtedly true that this strategy cannot guarantee huge profit margin, however, it enables to cover big market share, earning money by working on scale of sales (Porter, 1990). Therefore, this technique is especially popular among companies producing products oriented on mass consumption, such as Wal-Mart or fast food companies (Dickson, 1987, Helms et al., 1992). Meanwhile, small firms tend to have more obstacles by using cost leadership strategy, as the sale that is oriented to big market share requires appropriate size of the company (Wright, 1987). This type of strategy has the least choice of variances of marketing strategies. The offer of low prices enables company to occupy different segments of the market. However, it helps to increase the market share and to eliminate some competitors at the same time. Moreover, as most companies, which decide to be a part of the international market, mostly use marketing strength of their home country to decrease the expenses, such as low labor cost, low raw materials cost and this helps companies to establish compatible prices and be admitted by the customers abroad.

\section{H3: Cost leadership strategy has a positive impact on international market performance}




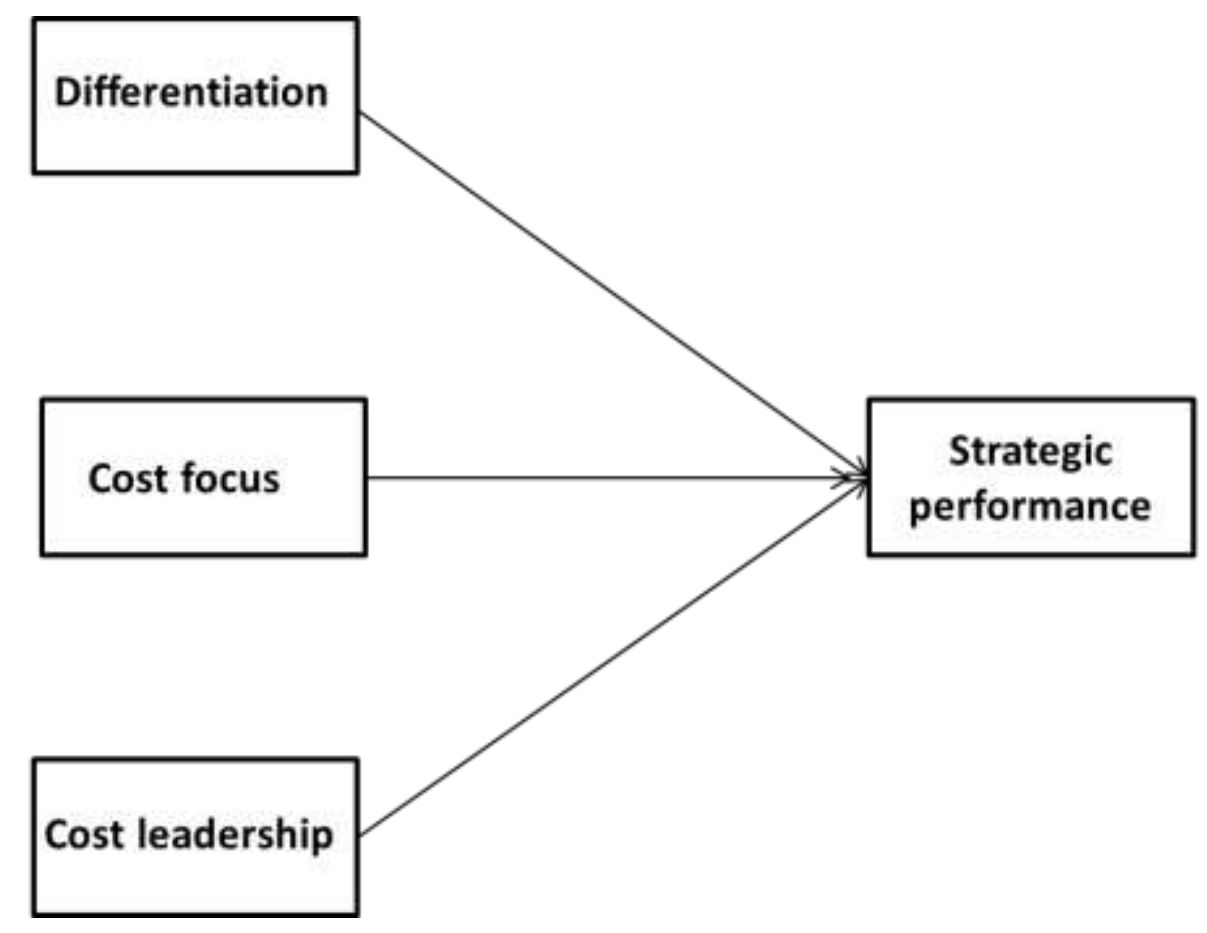

Figure 1: Business strategy research model

The research model depicts international strategy leading to international performance. Through a detailed review of the strategic management field, three main strategies were identified as conducive to strategic market success. Therefore, a relationship between differentiation, cost leadership, cost-focus strategy and international market experience has been hypothesized. In our model, we are assessing what is the best strategy for the success on the international market.

\section{Research methodology}

In order to explain the strategy-performance relationship of construction companies, a quantitative analysis was applied.

To meet the objectives of our study, we decided to employ a survey strategy. A questionnaire was developed with the help of the experts in the field of business strategy. All the scales were adopted from prior studies. A back-to-back translation from English to Chinese and then vice-versa to English was performed. By this action, the researcher ensured that no meaning had been lost during the translating process.

\section{Variable operationalization}

All the variables of the research model were measured with scales that were selected from previous research and were a direct result of previous studies and prior knowledge. Altogether six variables of the research model were analyzed measured. All the utilized scales exhibited an adequate level of reliability exceeding the value of 0.7 in all the studies that the scales were taken from. There were considerate alterations to the vocabulary of the consulted studies in order have them fit to the context of our current study.

Differentiation was adopted from a scale from Zott and Amit (2009). The items were measured according to a sevenpoint Likert scale and there were four items measured; product development and the focus on offering specialized product, focus on innovation in product delivery and focus on providing the distinctive product.

Cost-focus was adopted from a scale from Zott and Amit (2009). The items were measured according to a seven-point Likert scale and there were four items measured; product development and the focus onleadership in developing new 
operating procedures relative to competitors, operating efficiency relative to competitors, emphasizing economies of scale and scope with product development and the focus on minimizing product-related expenditures.The vocabulary was altered to better fit the context of this study.

Cost leadership was adopted from a scale from Chen and Tsou (2012).The variable was measured using a four item sale which was used to analyze: if the company manufacturing costs were lower than that of competitors; if the company continuously improves its processes in order to keep cost low, strives for product cost reduction, is constantly improving its operating efficiency; if its efficient internal operation system has decreased the cost of its products; if its economy of scale enables it to achieve a cost advantage and has a cost leadership position in the industry been achieved.

The strategic performance was adopted from a scale from Huselid (2005). The 4 items were measured using a sevenpoint Likert scale and included global business operations compared to major competitors.

The data collection process was conducted during the 2014 Canton Fair, the leading trade fair in the world, which was attended by great amount of businesspersons. The questionnaire link was distributed through existing business connections of the researcher and his colleagues. The link was distributed to totally 115 employees of Chinese construction companies. Clear instructions on how to fill the questionnaire were provided as well. After a certain period of time, a reminder was sent out to the sample group to guarantee higher response rate required for accurate statistical analysis. The data collection process was then concluded, generating 65 respondents in total.

\section{Data analysis and results}

The inference statistics method and SPSS statistical package were used to derive the results of the study. The data set contained 65 respondents, but after the missing values were eliminated for a sample of 58 respondent's analysis was conducted. As a part of the analysis, we first calculated descriptive statistics. Indicators of Standard deviation, mean, and skewness and kurtosis are indicated in table 1. The mean values of variables range from4,69 for strategic performance to 5,86 to Cost focus. Differentiation values are 5,72 and Cost leadership values are reported as 5,57.

Table 1: Descriptive statistics indicators

\begin{tabular}{lccccccccc}
\hline \multirow{2}{*}{ Variable name } & \multicolumn{2}{c}{ N } & \multicolumn{2}{c}{$\begin{array}{c}\text { Mean } \\
\end{array}$} & $\begin{array}{c}\text { Std. Error of } \\
\text { Mean }\end{array}$ & $\begin{array}{c}\text { Std. } \\
\text { Deviation }\end{array}$ & Skewness & Kurtosis & Minimum Maximum \\
\hline Differentiation & 58 & 0 & 5,7241 &, 15034 &, 80961 &,- 342 &,- 323 & 4,00 & 7,00 \\
Cost focus & 58 & 0 & 5,8621 &, 14124 &, 76060 &,- 788 &, 768 & 4,00 & 7,00 \\
Cost leadership & 58 & 0 & 5,5764 &, 16800 &, 90470 &,- 303 & $-1,151$ & 3,86 & 7,00 \\
Strategic & 58 & 0 & 4,6983 &, 25948 & 1,39735 &,- 177 &,- 708 & 2,00 & 7,00 \\
Performance & & & & & & & & & \\
\hline
\end{tabular}

In order to proceed with the structural model assessment, certain assumptions were required to fulfill. These included normality, assessment, sphericity and multicollinearity. Normality assessment was conducted by calculating Shapiro Wilk and Kolmogorov-Smirnov indexes showing sufficient normality of data. Furthermore, we confirmed the normality by displaying the data graphically. As the data was distributed linearly for all four variables; Differentiation, Cost focus, Cost leadership and Strategic performance, we concluded that normality assumption has been fulfilled. As a final step in our preliminary analysis, appropriateness of the measurement tool, i.e. the questionnaire was tested for reliability and validity. Composite reliability values were all well above 0.7 and with all the values for "if item removed" exceeded 0.7 Cronbach's alpha. 
Thus, all the original measures of authors were kept to measure the latent constructs. Validity was assessed through various ways, firstly, face validity of the instrument was confirmed and convergent validity by examining the correlation matrix, and finally, construct validity through factor analysis.. The next step in the analysis process is correlation analysis where we have seen that all the variables are correlated matching the theory, which we used to build our research model, and thus confirming the convergent validity. All the items were positively correlated and namely differentiation and cost leadership have $r$ values of 0.513 and 0.531 and $0.05<p<0.01$, meantime, cost leadership is also positively correlated $(r=0.39)$ with the strategic performance and $p$ value less than 0.05 .

As the condition of being positively correlated was fulfilled, we proceeded with multiple regression analysis. Performing multiple regression analysis enables us to see the impact of predictor variables on the dependent variable. Furthermore, a predictive value of the research model is given. In the table 3 values are displayed.

The variables of cost leadership, differentiation and cost focus were tested on a dependent variable of Strategic performance. In a model summary table, $R$ value of 0,66 and $R^{2}$ value of 0,435 indicate a high predictive value of our research model. This means that $43,5 \%$ of variance in Strategic performance can be explained by predictors Cost leadership, Differentiation, Cost focus.

Table 2: Correlations

\begin{tabular}{|c|c|c|c|c|c|}
\hline \multicolumn{2}{|c|}{ Correlations } & Differentiation & Cost focus & Cost leadership & Strategic Performance \\
\hline \multirow{3}{*}{ Differentiation } & Pearson Correlation & 1 &, $499^{* *}$ & ,257 &, $513^{* *}$ \\
\hline & Sig. (2-tailed) & & ,006 & , 179 & ,004 \\
\hline & $\mathrm{N}$ & 58 & 58 & 58 & 58 \\
\hline \multirow{3}{*}{ Cost focus } & Pearson Correlation &, $499^{* *}$ & 1 &, $524^{* *}$ &, $390^{*}$ \\
\hline & Sig. (2-tailed) & ,006 & &, 004 & ,036 \\
\hline & $\mathrm{N}$ & 58 & 58 & 58 & 58 \\
\hline \multirow{3}{*}{ Cost leadership } & Pearson Correlation & ,257 &, $524^{* *}$ & 1 &, $531^{* *}$ \\
\hline & Sig. (2-tailed) & , 179 & ,004 & &, 003 \\
\hline & $\mathrm{N}$ & 58 & 58 & 58 & 58 \\
\hline \multirow{3}{*}{ Strategic Performance } & Pearson Correlation &, $513^{* *}$ &, $390^{*}$ &, $531^{* *}$ & 1 \\
\hline & Sig. (2-tailed) & ,004 & ,036 &, 003 & \\
\hline & $\mathrm{N}$ & 58 & 58 & 58 & 58 \\
\hline
\end{tabular}

**. Correlation is significant at the 0.01 level (2-tailed).

*. Correlation is significant at the 0.05 level (2-tailed).

Table 3: Model Summary

\begin{tabular}{llccr}
\hline Model & $\mathrm{R}$ & $\mathrm{R}$ Square & $\begin{array}{c}\text { Adjusted R } \\
\text { Square }\end{array}$ & $\begin{array}{c}\text { Std. Error of the } \\
\text { Estimate }\end{array}$ \\
\hline & & & & \\
1 &, $660^{\mathrm{a}}$ &, 435 &, 368 & 1,11113 \\
\hline \multicolumn{2}{l}{ a. Predictors: (Constant), Cost leadership, Differentiation, Cost focus }
\end{tabular}

The ANOVA test was performed as well and coefficients were calculated to numerically represent the research model. Unstandardized beta values for variables are as follows, differentiation $\beta=0,735$ with a significance level $p<0.05$, cost 
focus $\beta=-109$, and cost leadership $\beta=0,699$. Both standardized are unstandardized coefficients together with $t$ and $p$ values can be seen in table 4 .

Finally, a $t$-test was performed in which we defined null hypothesis as $H_{0}:=$ hypothesizing opposite of each proposed relationship. For the mean regression coefficients, with 95\% confidence, null hypothesis can be rejected at $p<0.005$. Thus, we accept these hypotheses with adequate significance level of $p$ being less than 0.05 . In conclusion, we accept the following hypotheses:

H1 Differentiation strategy has a positive impact on strategic market performance; H3 Cost leadership strategy has a positive impact on strategic market performance;

In addition, model rejects $\mathrm{H} 2$ - Cost focus strategy has a positive impact on strategic market performance

Table 4: Coefficients

\begin{tabular}{|llrrrrr}
\hline Model & & Unstandardized Coefficients & \multicolumn{1}{c}{$\begin{array}{c}\text { Standardized } \\
\text { Coefficients } \\
\text { Beta }\end{array}$} & t & & \\
& & B & \multicolumn{1}{c}{ Std. Error } & \multicolumn{2}{c}{ Sig. } \\
\hline \multirow{4}{*}{1} & (Constant) & $-2,768$ & 1,885 & & $-1,469$ &, 154 \\
& Differentiation &, 735 &, 589 &, 426 & 2,457 &, 021 \\
& Cost_focus &,- 109 &, 361 &,- 059 &,- 302 &, 765 \\
& Cost_leadership &, 699 &, 272 &, 453 & 2,566 &, 017 \\
\hline
\end{tabular}

a. Dependent Variable: Strategic Performance

\section{Findings and implications of the study}

The company that decided to enter the international market should plan its action in order to succeed. The strategy of marketing actions depends on the goals, which the company aims and stipulates the behavior of the firm in future (Emeka, 2015). As two of three hypotheses of our research regarding Porter's generic strategies were accepted, we found that among all the factors, differentiation is a strategy that has a major impact on strategic performance on international markets. These findings correspond to a study performed by Siegel and Vitaliano (2007), Mackey, (2007), Hill, (1988).

The choice of being different from other companies has a crucial role due to huge variety of companies, especially for the one, which intends to enter the market on international level. The company should be ready to face even stronger and fiercer competition not only from local firms but also from other international companies $\mathrm{n}$ case of their service or goods are similar. Therefore, it is important to "stick" in minds of customers in order to be chosen by them, which will increase the profits of the firm (Porter, 1980, 1996).

The differentiation strategy varies in itself depending on the company choice of methods for reaching its goals: either to support the production with an interesting advertisement (Smith, 1956) or to create special image, which is one of the tools of the company's differentiation strategy as well. For instance, the company Apple providing mobile phones all over the world, created the image of uniqueness by supporting their phones with special platform of iOS. On the other hand, Chinese company Xiaomi stipulated the limited period within which customers could buy its products in the beginning of its operation. As it is obvious from mentioned examples, companies put much effort in using different tools to be unique in eyes of customers. At the same time, the strategy of differentiation enables companies to manipulate the price of their products. By creating special attitude toward the products of the firm, customers are ready to pay even higher price for being a part of created image. Owning unique product or having VIP service make people 


\section{Mirzaeva Dilafruz Faziljanovna, GaoYongqian \\ Effective Business Strategy for International Strategic Performance: An Empirical Study of Chinese Construction \\ Firms}

feel special as well (Tungate, 2009). Moreover, differentiation of the product or service can be reached by using innovations, which are also positively related to the international firm's performance (Hult, 2004, Hull and Rothenberg, 2008).

Cost leadership is another business strategy, which, according to the results obtained, affects strategic performance of firms significantly. The finding is in the line with previous works done regarding the existence of relationship between cost leadership and firm performance (Li, C. B., 2008). The strategy of providing low costs in comparison with other companies is the popular tool to be more competitive (Dess, 1997). Furthermore, by using this strategy, firms are increasing its market segment share, which can promise high volume of sales and good profits to the company at the same time (Porter, 1990). However, by using this strategy as the main strategy, companies are unable to increase their prices in the future for the reason that its customers get used to low prices. However, by using such a strategy, the company can rely on their customers, as they not switch to another companies product or service easily. As it was mentioned by Gronholdt (2000), the knowledge that the certain brands of the products have relatively low price is positively related to the loyalty of the buyers, which is much higher in comparison with the companies which pay more attention to their image. Furthermore, sometimes there can be association of low cost products with relatively low quality (Reitsperger and Daniel, 1993). Nonetheless, the contribution of cost leadership strategy is positively significant for market performance in our study. Popularity of Chinese goods can serve as an example of this strategy. Chinese producers successfully occupied many markets in the world offering attractive prices due to low labor costs.

The last finding in terms of the choice of strategies is that cost focus showing no significant relationship with strategic performance in international market. As the main purpose of this strategy is focusing on the creation of a special offer either by focusing on a certain country (Aulakh, 2000), market (Slater and Narver, 1996), products or service (Kaplan and Norton, 2001), it can be achieved by the reduction of expenses. Despite the fact that cost focus strategy and cost leadership are using the technique of reducing expenses, however, there should be a clear understanding between two strategies, and namely cost focus and cost leadership.

Albeit, the main tool of these two strategic paths is to decrease the expenses of the company, however, the policy of them is quite different. The main goal of the last strategy is occupation of as much shares of market as possible, therefore the company, which is intending to enter international market, is reducing its expenses and offer low prices. While, the former is focusing on one segment either product or s market, by this action the company is reducing its costs, as it doesn't expend efforts to seize the market, especially when it is on international level where the scope of markets is wide. Focusing on costs only enables the company to deal with a big share of the market, which is essential on the global level of operations. Furthermore, it makes the company to be too dependent on the demand of the focused market or chosen segment. In addition, the companies can face their inflexibility to reorganize its production or dictate certain terms to the customers. Therefore, the influence of cost focus strategy is insignificantly related to the market performance of companies, which are operating on the international level.

The study has also shown that Chinese firms are strategically successful on international markets, was approved within the current study. The evidence of strong competitiveness of Chinese companies can be obviously seen through their successful performance on international market (Child, 2005). The behavior of Chinese companies can be considered as a combination of two strategies, which were approved within our study, and namely - differentiation and cost leadership strategies. By using innovations, they are decreasing their expenses and thus can offer cheap prices that make them so popular among others (Liu, 2002). Furthermore, nowadays, Chinese multinational companies are working hard on creation of unique image of their products, by increasing the quality of service and using marketing technique. In nutshell, research findings were found to be quite valuable and innovative. The major research contribution within the field of strategy falls under theoretical adjustment of the importance of proper strategy in international performance.

Even though such research has been a part of prior work, none of them were tested in the sample of Chinese construction firm, thus confirming and validating the existing theory on how strategy plays an important role in market performance. 
Limitations and future prospects

Even though, the objectives of the study were successfully met the requirements of research questions to be answered, still certain limitations do exist. First, a self-reported measure for strategy and strategic market performance may not be the best measurement. Actual observation and secondary data from external sources could have been used to complement the current measurement tool. However, due to limited resources of the researcher, triangulation of methods in general could not be achieved. Next, the study only superficially approaches strategy, and does not go deep into various facets of it, such as product strategy, price strategy and many others. Specific strategies may be of interest of future studies. Also, future research should focus on particular steps of strategy implementation that would lead to a desired organizational outcome. As an impact of international experience on firm performance was confirmed and proved to vary according to a firm's level of international experience in a region, it would be interesting to combine the variables of organizational learning, capabilities, and international experience with our business strategy model.

Moreover, a limited sample of only 58 international firms was used to perform the analysis. It is not possible to derive general conclusions only from a small sample of firms belonging to construction industry only. A larger sample, consisting of firms belonging to various industries should be tested by other researchers to validate the findings of our study. Lastly, we have only tested for influence of differentiation, cost focus and cost leadership on the dependent variable of strategic performance. Future studies could focus on evaluating the impact of these strategies on financial performance, innovation or other organizational outcome. Such research would enable firms to know which type of strategy is conducive to the organizational outcome they strive to achieve.

\section{Conclusion}

We aimed to find out what international market strategy generates international success in terms of strategic performance. The objective of this study was to examine the effect cost leadership, differentiation, cost focus have an effect on market, strategic performance, which was successfully achieved and fulfilled. The analysis of various business and marketing strategies and their impact overall, financial and strategic performance of Chinese construction companies was conducted using a descriptive and quantitative method. In addition, we assessed the types of strategy, levels of strategy of our targeted sample. We found out how successful these companies on the international markets are. Companies with international experience are overall better at creating and implementing their strategy required to achieve a more suited strategic and financial performance on the international and global market because they already have the specific knowledge needed to execute a successful business strategy.

This can put them way ahead of the competition and allow them to develop and expand even more. The degree of internalization within a company or organization can be an important determinant of the type of strategy or program best suited to a certain firm. Those companies with previous international experience on the market find that they are much better suited to direct exporting as market entry strategy. The international firm operations will bring skills which are particularly desirable and beneficial for senior leaders to have, which include expanding an understanding for international business and the capacity to grasp complex new market trends and information, the ability to engage quickly with new partners and also a cultural awareness and the capacity to bring people together, create relationships, connections and influence those who may be culturally or politically different.

\section{References}

- Aghazadeh, H., 2015. Strategic Marketing Management: Achieving Superior Business Performance through Intelligent Marketing Strategy. Procedia-Social and Behavioral Sciences, 207, pp.125-134, CrossRef

- Aulakh, P. S., Rotate, M., \&Teegen, H. (2000). Export strategies and performance of firms from emerging economies: Evidence from Brazil, Chile, and Mexico. Academy of Management journal, 43(3), 342-361, CrossRef

- Barney, J., 1991. Firm resources and sustained competitive advantage.Journal of management, 17(1), pp.99120, $\underline{\text { CrossRef }}$

- Child, J., \& Rodrigues, S. B. (2005). The internationalization of Chinese firms: A case for theoretical extension? [1]. Management and organization review, 1(3), 381-410, CrossRef 
- Dess, G. G., Lumpkin, G. T., \&Covin, J. G. (1997). Entrepreneurial strategy making and firm performance: Tests of contingency and configurational models. Strategic management journal, 18(9), 677-695, CrossRef, CrossRef

- $\quad$ Dickson, P.R., 1992. Toward a general theory of competitive rationality. The Journal of Marketing, pp.69-83, CrossRef

- Gronholdt, L., Martensen, A., \&Kristensen, K. (2000). The relationship between customer satisfaction and loyalty: cross-industry differences. Total quality management, 11(4-6), 509-514, CrossRef

- Hill, C. W. (1988). Differentiation versus low cost or differentiation and low cost: A contingency framework. Academy of Management Review, 13(3), 401-412, CrossRef, CrossRef

- Hull, C. E., \& Rothenberg, S. (2008). Firm performance: The interactions of corporate social performance with innovation and industry differentiation.Strategic Management Journal, 29(7), 781-789, CrossRef

- Kaplan, R. S., \& Norton, D. P. (2001). The strategy-focused organization: How balanced scorecard companies thrive in the new business environment. Harvard Business Press, CrossRef

- $\quad$ Lages, L.F., Jap, S.D. and Griffith, D.A., 2008. The role of past performance in export ventures: a short-term reactive approach. Journal of International Business Studies, 39(2), pp.304-325, CrossRef

- Li, C. B., \& Li, J. J. (2008). Achieving superior financial performance in China: Differentiation, cost leadership, or both? Journal of international Marketing, 16(3), 1-22, CrossRef

- Liu, H., \& Li, K. (2002). Strategic Implications of Emerging Chinese Multinationals:: The Haier Case Study. European Management Journal, 20(6), 699-706, CrossRef

- Luo, Yadong. "Business strategy, market structure, and performance of international joint ventures: The case of joint ventures in China." MIR: Management International Review (1995): 241-264.

- Mackey, A., Mackey, T. B., \& Barney, J. B. (2007). Corporate social responsibility and firm performance: Investor preferences and corporate strategies. Academy of management review, 32(3), 817-835, CrossRef

- $\quad$ Porter, M.E., 1979. The structure within industries and companies' performance. The review of economics and statistics, pp.214-227, CrossRef

- Reitsperger, W. D., Daniel, S. J., Tallman, S. B., \&Chismar, W. G. (1993). Product quality and cost leadership: compatible strategies?. MIR: Management International Review, 7-21.

- Sabherwal, R. and Chan, Y.E., 2001. Alignment between business and IS strategies: A study of prospectors, analyzers, and defenders. Information systems research, 12(1), pp.11-33, CrossRef

- Shapiro, C., 1989. The theory of business strategy. The Rand journal of economics, 20(1), pp.125-137. CrossRef

- Siegel, D. S., \&Vitaliano, D. F. (2007). An empirical analysis of the strategic use of corporate social responsibility. Journal of Economics \& Management Strategy, 16(3), 773-792, CrossRef

- $\quad$ Slater, S. F., \&Narver, J. C. (1996). Competitive strategy in the market-focused business. Journal of marketfocused management, 1(2), 159-174, CrossRef

- Smith, W. R. (1956). Product differentiation and market segmentation as alternative marketing strategies. The Journal of Marketing, 3-8, CrossRef

- Tungate, M. (2009). Luxury world: the past, present and future of luxury brands. Kogan Page Publishers.

- Wright, P., Kroll, M., Tu, H. and Helms, M., 1991. Generic strategies and business performance: an empirical study of the screw machine products industry. British Journal of management, 2(1), pp.57-65, CrossRef

- Zott, C. and Amit, R., 2009. The business model as the engine of network-based strategies. The network challenge, pp.259-275. 